\title{
PENGARUH PENERAPAN BUDAYA KERJA POSITIF TERHADAP PENINGKATAN MUTU PENDIDIKAN PADA SMP NEGERI 1 SAKRA BARAT SEMESTER GANJIL TAHUN PELAJARAN 2017/2018
}

\author{
Masyhudi \\ Kepala SMP Negeri 1 Sakra Barat \\ smpnegeri1sakrabarat@gmail.com
}

\begin{abstract}
Abstrak: Penelitian ini dilakukan sebagai salah satu upaya untuk mengetahui penyebab terhambatnya pekembangan mutu proses pendidikan pada SMP Negeri 1 Sakra Barat melalui penerapan budaya kerja positif, bagaimana langkah-langkah penerapan budaya kerja positif, dan bagaimana respon personil sekolah terhadap penerapan budaya kerja positif di SMP Negeri 1 Sakra Barat dipantau dari peningkatan mutu proses pendidikan. Penelitian dilaksanakan dalam dua Siklus tindakan yakni siklus 1 yang dumulai dari tanggal 17 Juli 2017 sampai 29 September 2017, dan pelaksanaan siklus II dimulai dari tanggal 2 Oktober sampai 31 Oktober 2017. Desain penelitian mengadopsi desain penelitian Hopkin dengan tahapan audit, perencanaan konstruk, penetapan target, tindakan atau implementasi, evaluasi, cek kemajuan, dan pelaporan. Metode pengumpulan data menggunakan teknik observasi dan wawancara, dan alat pengumpulan data menggunakan teknik intrumentasi dengan mengadopsi intrumen penilaian perencanaan dan pengembangan sekolah dengan 6 bidang pokok yakni bidang pengelolaan, bidang pendidik dan tenaga kependidikan, bidang sarpras, bidang pembiayaan, bidang akademik, dan bidang lingkungan. Berdasarkan hasil penelitian diketahui bahwa langkah - langkah penerapan budaya kerja positif di SMP Negeri 1 Sakra Barat diawali dengan penetapan rumusan visi, misi, dan tujuan sekolah secara jangka pendek dan jangka panjang, dan di sepakati dalam rapat kepala sekolah, guru, dan tenaga administrasi, dan dilanjutkan dengan penetapan Standar Operasional Prosedur (SOP) kerja yang terarah dan terpokus pada hasil rumusan visi, misi, dan tujuan sekolah baik SOP yang berhubungan dengan pembelajaran peserta didik dan pendampingan kegiatan ektrakurukuler dan program-program pengembangan diri. Berhubungan dengan respon personil SMP Negeri 1 Sakra Barat terhadap penerapan budaya kerja positif dipantau dari peningkatan mutu proses pendidikan didapatkan kesimpulan bahwa semua personil sekolah dari guru sampai dengan peserta didik merepon dengan baik, hal ini dibuktikan dengan peningkatan hasil analisis perhitungan intrumentasi perencanaan dan pengembangan sekolah (PPS) dari tindakan tahap pertama ke tindakan tahap kedua sebesar 3,79 poin, dan diperkuat dengan keberhasilan prestasi akdemik, dan prestasi keterampilan peserta didik yang pada semester ganjil 2017/2018 meraih peringkat akademik peringkat 10 besar

Fondatia: Jurnal Pendidikan Dasar

Volume 1, Nomor 2, Agustus 2017; e-ISSN 2579-6194; 68-81
\end{abstract}


tingkat kabupaten Lombok Timur, peraih medali emas olahraga karate PORKAB Lotim 2017, dan peringkat juara umum olimpiade siswa Provinsi Nusa Tenggara Barat 2017 bidang atletik.

Kata Kunci : Budaya Kerja Positif, mutu proses pendidikan.

\section{A. Pendahuluan}

Tahun 2017 Tanggal 20 November SMP Negeri 1 Sakra Barat akan berusian 33 Tahun sejak dibangun dan diresmikan Menteri Pendidikan Nasional Fuad Hasan pada saat itu. Lembaga sekolah ini telah banyak mencetak lulusan yang saat ini menduduki jabatan penting lembaga pendidikan tinggi, maupun jabatan pemerintahan. Pada era tahun 1990an SMP 1 Sakra Barat yang pada waktu adalah SMP Negeri 3 Sakra merupakan sekolah yang sangat disegani dari output lulusan dan kecerdasan siswanya, pada tahun-tahun tersebut siswa siswinya selalu menjadi juara pada setiap lomba baik ditingkat kecamatan, kabupaten, maupun provinsi. Merupakan suatu kebanggaan yang luar biasa yang harus dipertahankan.

Peneliti dipercaya sebagai kepala sekolah di lembaga pendidikan ini pada awal semester ganjil 2015/2016. Kondisi yang sangat jauh berbeda dengan apa yang sebelumnya peneliti dengar dan lihat. Kondisi yang umum seperti lembaga-lembaga pendidikan SLTP sekarang ini, bahkan kondisinya lebih parah pada beberapa komponen pendukung prosesnya.

Merupakan kewajiban dan tanggung jawab peneliti untuk mengembalikan sejarah masa lalu terulang kembali, impian utama peneliti setalah mengetahui keadaan ini adalah menjadikan lembaga SMP Negeri 1 Sakra Barat menjadi pelopor pendidikan berkualitas dan diperhitungkan harus dicapai kembali melalui upaya-upaya positif. dan konstruktif. Setelah melakukan evaluasi dan analisa kondisi secara keseluruhan, peneliti menemukan banyak sekali kesenjangan yang membutuhkan perbaikan dan pengembangan untuk dapat meraih impian tersebut. Permasalahan inti yang sangat nampak kesenjangannya menurut hasil observasi peneliti adalah budaya kerja personil sekolah yang tidak mencerminkan tujuan yang terarah dan sistematis, sehingga output kegiatan dan program sekolah hanya sebatas laporan diatas kertas. 
Sebagai upaya untuk melakukan revitalisasi kondisi kinerja yang ideal maka diperlukan sebuah sistem yang dapat membangkitkan kembali semangat prestasi warga SMP Negeri 1 Sakra Barat melalui penerapan budaya kerja positif, untuk meningkatkan mutu pendidikan yang mencakup enam bidang pokok perencanaa dan pengembangan Sekolah yakni bidang pengelolaan, pendidik dan tenaga kependidikan, pembiayaan, sarpras, akademik, dan lingkungan.

Berkaitan dengan budaya kerja Prof. Dr. Djokosantoso Moeljono sesuai yang dikutip dari Eldison. H. menyatakan " bahwa Budaya kerja merupakan faktor paling dominan terhadap perilaku organisasi. Oleh karenanya dalam upaya mencapai keberhasilan organisasi, maka sangat diperlukan membangun budaya kerja organisasi, karena secara realistis budaya kerja dan keberhasilan organisasi memiliki keterkaitan yang erat. Budaya kerja organisasi mencakup nilai-nilai yang harus tercermin dalam sikap dan perilaku setiap individu dalam organisasi yang meliputi integritas, profesionalisme, keteladanan, dan penghargaan kepada SDM, yang secara bersamasama berpengaruh terhadap “Produktivitas Pelayanan”. (dalam Mulyasa, 2002)

Triguno, 2004:1 dalam Hamidi, 2017 menjelaskan bahwa “ Budaya kerja merupakan sistem nilai, persepsi, perilaku dan keyakinan yang dianut oleh setiap karyawan tentang makna kerja dan refleksinya dalam kegiatan mencapai tujuan organisasi dan Sebenarnya budaya kerja sudah lama dikenal manusia, namun belum disadari bahwa sebuah keberhasilan kerja berakar pada nilai-nilai yang dimiliki dan perilaku yang menjadi kebiasaan. Nilai-nilai tersebut bermula dari adat-istiadat, agama, norma dan kaidah yang menjadi keyajinan pada diri pelaku kerja atau organisasi. Nilainilai yang menjadi kebiasaan tersebut dinamakan budaya kerja.

Dalam konteks lingkungan pendidikan unsur budaya kerja yang baik harus menjadi pokus pertama yang harus diperbaiki karena menyangkut kelancaran keseluruhan proses pendidikan untuk menghasil output yang baik sehingga tercapainya amanah Pendidikan secara nasioanl yang berfungsi untuk mengembangkan pengetahuan dan membentuk watak serta peradaban bangsa yang bermartabat dalam rangka mencerdaskan kehidupan bangsa, bertujuan untuk berkembangnya potensi peserta didik agar menjadi manusia yang beriman, bertaqwa kepada Tuhan Yang Maha 
Esa, berakhlak mulia, sehat, berilmu, cakap, kreatif, mandiri, dan menjadi warga Negara yang demokratis dan bertanggung jawab. Untuk mencapai tujuan yang dimaksud diatas, maka penyelenggaraan pendidikan harus mampu memperdayakan semua komponen masyarakat melalui peran serta dalam penyelenggaraan dan pengendalian mutu pendidikan. Keikutsertaan semua komponen penyelenggaraan pendidikan tersebut menjadi sangat penting mengingat persaingan dalam kerangka meningkatkan mutu pendidikan baik dalam taran mikro meso maupun makro sangat ketat. Dan peningkatan mutu pendidikan merupakan sasaran pembangunan dibidang pendidikan nasional dan merupakan bagian integral dari upaya peningkatan kualitas manusia Indonesia secara kaffah/menyeluru) ( Mulyasa, 2003 :31-32).

Menurut Robbin (1993) dalam saravine, 2016 menjelaskan bahwa pembentukan budaya kerja dalam sebuah organisasi harus memenuhi 10 karakteristik inti yakni :

1) Member identity, yaitu identitas anggota dalam organisasi secara keseluruhan, dibandingkan dengan identitas dalam kelompok kerja atau bidang profesi masing-masing,

2) Group emphasis, yaitu seberapa besar aktivitas kerja bersama lebih ditekankan dibandingkan kerja individual,

3) People focus, yaitu seberapa jauh keputusan manajemen yang diambil digunakan untuk mempertimbangkan keputusan tersebut bagi anggota organisasi,

4) Unit integration, yaitu seberapa jauh unit-unit di dalam organisasi dikondisikan untuk beroperasi secara terkoordinasi,

5) Control, yaitu banyaknya / jumlah peraturan dan pengawasan langsung digunakan untuk mengawasi dan mengendalikan perilaku karyawan,

6) Risk tolerance, yaitu besarnya dorongan terhadap karyawan untuk menjadi lebih agresif, inovatif, dan berani mengambil risiko,

7) Reward criteria, yaitu berapa besar imbalan dialokasikan sesuai dengan kinerja karyawan dibandingkan alokasi berdasarkan senioritas, favoritism, atau faktor-faktor nonkinerja lainnya, 
8) Conflict tolerance, yaitu besarnya dorongan yang diberikan kepada karyawan untuk bersikap terbuka terhadap konflik dan kritik,

9) Means-ends orientation, yaitu intensitas manajemen dalam menekankan pada penyebab atau hasil, dibandingkan pada teknik dan proses yang digunakan untuk mengembangkan hasil,

10) Open-system focus, yaitu besarnya pengawasan organisasi dan respon yang diberikan untuk mengubah lingkungan eksternal.

Sedangkan Nilai-nilai yang harus dipenuhi didalam budaya kerja organisasi sebagai nilai vital, materiil, dan roh dalam mencapai tujuan organisasi menurut Kotter dan Heskett (1992:22) sebagaiman dikutip dari saravine, 2016 adalah :

1. Disiplin; Perilaku yang senantiasa berpijak pada peraturan dan norma yang berlaku di dalam maupun di luar perusahaan. Disiplin meliputi ketaatan terhadap peraturan perundang-undangan, prosedur, berlalu lintas, waktu kerja, berinteraksi dengan mitra, dan sebagainya.

2. Keterbukaan; Kesiapan untuk memberi dan menerima informasi yang benar dari dan kepada sesama mitra kerja untuk kepentingan perusahaan.

3. Saling menghargai; Perilaku yang menunjukkan penghargaan terhadap individu, tugas dan tanggung jawab orang lain sesama mitra kerja.

4. Kerjasama; Kesediaan untuk memberi dan menerima kontribusi dari dan atau kepada mitra kerja dalam mencapai sasaran dan target perusahaan.

Dan karakteristik yang harus terpenuhi dalam penerapan budaya kerja positif lembaga sekolah Stephen P. Robbins, 2004 merincikannya sebagai berikut :

1. Tingkat tanggung jawab, kebebasan dan independensi warga atau personil sekolah, komite sekolah dan lainnya dalam berinisiatif Tingkat tanggung jawab, kebebasan dan independensi warga atau personil sekolah, komite sekolah dan lainnya dalam berinisiatif;

2. Sejauh mana para personil sekolah dianjurkan dalam bertindak progresif, inovatif dan berani mengambil resiko; 
Masyhudi

3. Sejauh mana sekolah menciptakan dengan jelas visi, misi, tujuan, sasaran sekolah, dan upaya mewujudkannya;

4. Sejauh mana unit-unit dalam sekolah didorong untuk bekerja dengan cara yang terkoordinasi;

5. Tingkat sejauh mana kepala sekolah memberi informasi yang jelas, bantuan serta dukungan terhadap personil sekolah;

6. Jumlah pengaturan dan pengawasan langsung yang digunakan untuk mengawasi dan mengendalikan perilaku personil sekolah

7. Sejauh mana para personil sekolah mengidentifkasi dirinya secara keseluruhan dengan sekolah ketimbang dengan kelompok kerja tertentu atau bidang keahlian professional;

8. Sejauh mana alokasi imbalan diberikan didasarkan atas kriteria prestasi;

9. Sejauh mana personil sekolah didorong untuk mengemukakan konflik dan kritik secara terbuka;

10. Sejauh mana komunikasi antar personil sekolah dibatasi oleh hierarki yang formal.

Defenisi mutu memiliki konotasi yang bermacam-macam tergantung orang yang memakainya. Mutu berasal dari bahasa latin yakni "Qualis" yang berarti what kind of (tergantung kata apa yang mengikutinya). Mutu menurut Deni ialah kesesuaian dengan kebutuhan. Mutu menurut Juran ialah kecocokan dengan kebutuhan. (dalam Usman, 2006). Menurut Hari Sudrajad (2005) pendidikan yang bermutu adalah pendidikan yang mampu menghasilkan lulusan yang memiliki kemampuan atau kompetensi, baik kompetensi akademik maupun kompetensi kejuruan, yang dilandasi oleh kompetensi personal dan sosial, serta nilai-nilai akhlak mulia, yang keseluruhannya merupakan kecakapan hidup (life skill). Lebih lanjut Sudrajad mengemukakan pendidikan bermutu adalah pendidikan yang mampu menghasilkan manusia seutuhnya (manusia paripurna) atau manusia dengan pribadi yang integral (integrated personality) yaitu mereka yang mampu mengintegralkan iman, ilmu, dan amal.

Dan ciri-ciri pendidikan yang bermutu adalah :1) Sekolah berfokus pada pelanggan, baik pelanggan internal maupun pelanggan eksternal, Sekolah berfokus pada upaya 
untukmencegah masalah yang muncul, dalam makna ada komitmen untuk bekerja secara benar dari awal, 2) sekolah memiliki investasi pada sumber dayanya, Sekolah memiliki strategi untuk mencapai kualitas, baik ditingkat pimpinan, tenaga akademik, maupun tenaga administrative, 3) sekolah mengelola atau memperlakukan keluhan sebagai umpan balik untuk mencapai kualitas dan memposisikan kesalahan sebagai instrument untuk berbuat benar pada peristiwa atau kejadian berikutnya, 4)Sekolah memiliki kebijakan dalam perencanaan untuk mencapai kualitas, baik dalam perencanaan jangka pendek, jangka menengah, maupun jangka panjang, 5)Sekolah mengupayakan proses perbaikan dengan melibatkan semua orang sesuai dengan tugas pokok, fungsi, dan tanggung jawabnya, 6)Sekolah mendorong orang yang dipandang memiliki kreativitas, mampu menciptakan kualitas, dan merangsang yang lainnya agar dapat bekerja secara berkualitas, 7) Sekolah memperjelas peran dan tanggung jawab setiap orang, termasuk kejelasan arah kerja secara vertical dan horizontal, 8) Sekolah memiliki strategi dan criteria evaluasi yang jelas, 9) Sekolah memandang atau menempatkan kualitas yang dicapai sebagai jalan untuk memperbaiki kualitas layanan lebih lanjut, 10)Sekolah memandang kualitas sebagai bagian integral dari budaya kerja, dan 11) Sekolah menempatkan peningkatan kualitas secara terus menerus sebagai keharusan.

\section{B. Metode Penelitian}

Penelitian Tindakan Sekolah ini dilakukan di SMPN 1 Sakra Barat terhadap keseluruhan tenaga pendidik, tenaga kependidikan, komite sekolah dan pesertadidik. Waktu pelaksanaan penelitian ini dimulai 1 Agsutus 2017 sampai dengan 31 Oktober 2017. Penelitian ini, menggunakan prosedur penelitian desain Hopkin yang melalui tahapan start - audit - perencanaan konstruk - perencanaan tindakan (target, tugas, criteria keberhasilan) - implementasi dan evaluasi - cek hasil - pelaporan. Teknik pengumpulan data yang digunakan adalah teknik observasi langsung dengan menggunakan instrumen angket perencanaan dan pengembangan sekolah sebagai alat pengumpulan data, dan proses analisis menggunakan analisis deskriftif persentase untuk mengetahui peningkatan mutu pendidikan SMP negri 1 Sakra Barat sebelum dan stelah penerapan budaya kerja positif., dan Rumus perhitungannya adalah : 


\section{$\mathbf{N}=\mathbf{R} / \mathbf{S M} \times \mathbf{1 0 0} \%$}

Keterangan:

$\mathrm{N}=$ Nilai dalam persen

$\mathrm{R}=$ Skor nyata yang dicapai

$\mathrm{SM}=$ Skor ideal ( Ngalim Purwanto, 2001: 102)

Dan Skor rata - rata ideal untuk masing bidang adala 15.

Dengan kriterum prsentase sebagai berikut :

\begin{tabular}{|l|l|l|}
\hline Kualifikasi & Kategori & $\begin{array}{l}\text { Rentang 0,10- } \\
0,100 \%\end{array}$ \\
\hline Baik Sekali & A & $90-100$ \\
Baik & B & $70-89$ \\
Cukup & C & $50-69$ \\
Kurang & D & $30-49$ \\
Kurang sekali & E & $10-29$ \\
\hline
\end{tabular}

Sedangkan keabsahan data diukur dari ketekunan pengamatan yaitu mencari secara konsisten interpretasi dengan berbagai cara dalam kaitan dengan proses analisa yang konstan dan tentative.

\section{Hasil dan Pembahasan}

Pelaksanaan penelitian dilakukan dimulai dari 17 Juli 2017 sampai dengan 29 September 2017. Kegiatan pertama adalah melaksanakan rapat penyusunan Visi, Misi, Tujuan, program kerja, dan program pembelajaran baik intrakurukuler maupun ekstrakurikuler sekolah, serta program-program lain yang mendukung tercapainya tujuan sekolah yang sudah ditetapkan. Implementasi program dan kegiatan observasi dilakukan mulai tanggal 23 Juli 2017 sampai dengan tanggal 15 September 2017 dengan hasil observasi dan evaluasi kegiatan 
menunjukkan hasil penilaian refleksi kinerja personil SMP Neger 1 Sakra Barat dengan sebagai berikut :

TABEL REKAPITULASI ANGKET REFLEKSI BUDAYA KERJA SEBELUM TINDAKAN

\begin{tabular}{|c|c|c|c|}
\hline Bidang & Sub Bidang & Jumlah & Rata-rata \\
\hline \multirow{3}{*}{ PENGELOLAAN } & Perencanaan & 7 & \multirow{3}{*}{6,3} \\
\hline & Pelaksanaan & 7 & \\
\hline & Pengawasan dan Evaluasi & 5 & \\
\hline \multirow{3}{*}{$\begin{array}{l}\text { PENDIDIK DAN } \\
\text { TENAGA } \\
\text { KEPENDIDIKAN }\end{array}$} & Kolaborasi & 7 & \multirow{3}{*}{6,6} \\
\hline & Interaksi & 7 & \\
\hline & Kinerja & 8 & \\
\hline \multirow{3}{*}{$\begin{array}{l}\text { SARANA } \\
\text { dan } \\
\text { PRASARANA }\end{array}$} & Perencanaan & 4 & \multirow{3}{*}{4} \\
\hline & Pengadaan & 5 & \\
\hline & Perawatan dan Perbaikan & 4 & \\
\hline \multirow{3}{*}{ PEMBIAYAAN } & Sumber Dana & 4 & \multirow{3}{*}{6} \\
\hline & Alokasi Pembiayaan & 6 & \\
\hline & Mekanisme Pertanggungjawaban & 8 & \\
\hline \multirow{4}{*}{ AKADEMIK } & Isi & 7 & \multirow{4}{*}{8} \\
\hline & Proses & 8 & \\
\hline & Penilaian & 9 & \\
\hline & Kelulusan & 8 & \\
\hline \multirow[t]{3}{*}{ LINGKUNGAN } & Perencanaan & 6 & \multirow{3}{*}{5,6} \\
\hline & Pengembangan & 5 & \\
\hline & Evaluasi & 6 & \\
\hline \multicolumn{2}{|l|}{ Total Komulatif } & 118 & 6,8 \\
\hline \multicolumn{2}{|c|}{ Percentase dan Kategori $6,8 / 15 \times 100 \%=0,45 \%$} & \multicolumn{2}{|c|}{ D ( Kurang) } \\
\hline
\end{tabular}

Dari hasil rekapitulasi angket refleksi budaya kerja personil SMP Negeri 1 Sakra Barat sebelum pelaksnaan tindakan didapatkan persentase yang dalam kategori kurang dengan percentase angka $0,45 \%$. Jika dilihat dari rata- rata per bidang kondisi yang sangat butuh perhatian adalah bidang sarana dan prasarana. Namun dalam pelaksanaan tindakan penelitian yang menjadi pokus objek adalah Sumber daya Manusia yang ada pada lembaga SMP Negeri 1 Sakra Barat. Hal ini disebabkan asumsi awal penerapan

budaya kerja positif yang menjadi variable inti adalah personil sekolah, dan jika respon personil terhadap penerapannya diyakini bahwa semua bidang lainya akan ditunjang termasuk bidang sarana. Setelah pelaksanaan tindakan tahap awal (siklus I) didaptkan hasil rekapitulasi angket repleksi budaya kerja personil meningkat menjadi $0,61 \%$ dengan kategori C ( Cukup sebagaimana terlihat pada table berikut : 
TABEL REKAPITULASI ANGKET REFLEKSI BUDAYA KERJA SIKLUS I

\begin{tabular}{|c|c|c|c|}
\hline Bidang & Sub Bidang & Jumlah & Rata-rata \\
\hline \multirow{3}{*}{ PENGELOLAAN } & Perencanaan & 13 & \multirow{3}{*}{11,7} \\
\hline & Pelaksanaan & 12 & \\
\hline & Pengawasan dan Evaluasi & 10 & \\
\hline \multirow{3}{*}{$\begin{array}{l}\text { PENDIDIK DAN } \\
\text { TENAGA } \\
\text { KEPENDIDIKAN }\end{array}$} & Kolaborasi & 11 & \multirow{3}{*}{10,6} \\
\hline & Interaksi & 11 & \\
\hline & Kinerja & 10 & \\
\hline \multirow{3}{*}{$\begin{array}{l}\text { SARANA } \\
\text { dan } \\
\text { PRASARANA }\end{array}$} & Perencanaan & 7 & \multirow{3}{*}{7} \\
\hline & Pengadaan & 7 & \\
\hline & Perawatan dan Perbaikan & 7 & \\
\hline \multirow{3}{*}{ PEMBIAYAAN } & Sumber Dana & 6 & \multirow{3}{*}{8} \\
\hline & Alokasi Pembiayaan & 9 & \\
\hline & Mekanisme Pertanggungjawaban & 9 & \\
\hline \multirow{4}{*}{ AKADEMIK } & Isi & 8 & \multirow{4}{*}{9,8} \\
\hline & Proses & 9 & \\
\hline & Penilaian & 11 & \\
\hline & Kelulusan & 11 & \\
\hline \multirow[t]{3}{*}{ LINGKUNGAN } & Perencanaan & 8 & \multirow{3}{*}{8,3} \\
\hline & Pengembangan & 9 & \\
\hline & Evaluasi & 8 & \\
\hline \multicolumn{2}{|l|}{ Total Komulatif } & 241 & 9,23 \\
\hline \multicolumn{2}{|c|}{ Percentase dan Kategori $9,23 / 15 \times 100 \%=0,61 \%$} & \multicolumn{2}{|c|}{ C (CUKUP) } \\
\hline
\end{tabular}

Pada table diatas nampak adanya peningkatan pada masing bidang, namun masih diperlukan upaya penguatan - penguatan pada bidang- bidang penunjang. Dari kesimpulan hasil analisis tindakan siklus maka, rencana tindakan siklus II disusun sebagai upaya tindak lanjut dari hasil tindakan siklus I. khusunya pada upaya memaksimalkan partisipasi warga kesekolah terhadap pengembangan bidang sarana, dan upaya aktif personil sekolah terhadap bidang pembiayaan. Langkah-langkah perencanaan yang disusun pada tindakan siklus II adalah : Memaksimalkan pembinaan dan

upaya terobosan ekternal yang mampu menunjang tingkat ketersedian sarana dan prasaran, serta melakukan pembinaan terhadap warga sekolah untuk memanfaatkan sarana yang ada secara maksimal melalui peltihan penguasaan IT. Sehingga terciptanya efesiensi dan efektifitas kerja pendidik dan tenaga kependidikan, Memaksimalkan peran 
aktif komite, pendidik, dan tenaga kependidikan dalam proses identifikasi sumber dana, Rencana lain yang berkaitan dengan bidang lingkungan.

Implementasi rencana pada siklus II dilaksanakan mulai 2 Oktober 2017 sampai dengan 31 Oktober 2017, dengan kegiatan sebagai berikut : a) Melaksankan jalinan kemitraan dengan pihak ekternal sekolah, seperti komite sekolah, pihak dinas pendidikan Kabupaten kota, dan lembaga-lembaga lain untuk menunjang kelancaran proses pendidikan di SMP Negeri 1 Sakra Barat, melalui kegiatan rapat dan kiunjungan kemitraan. b) Melakukan penguatan program- program pembinaan lingkungan secara internal melalui program pemilihan pahlawan lingkungan bagi peserta didik, dan pengklasifikasian wilayah tanggung jawab bina lingkungan secara klasikal peserta didik, c) Melaksanakan program dan kegiatan yang menunjang peningkatan profesionalisme tenaga pendidik dan kependidikan. Setelah berbagai tahap implementasi program dilaksanakan, peneliti melakukan analisa keterlaksanaan dan tingkat perkembangan kinerja warga sekolah dengan hasil angkat refleksi kinerja siklus II didaptkan pesentase $0,88 \%$ dengan kategori Baik. Sebagaimana terlihat pada table berikut :

TABEL REKAPITULASI ANGKET REFLEKSI BUDAYA KERJA SIKLUS II

\begin{tabular}{|c|c|c|c|}
\hline Bidang & Sub Bidang & Jumlah & Rata-1 \\
\hline \multirow{3}{*}{ PENGELOLAAN } & Perencanaan & 16 & \multirow{3}{*}{13,3} \\
\hline & Pelaksanaan & 13 & \\
\hline & Pengawasan dan Evaluasi & 11 & \\
\hline \multirow{3}{*}{$\begin{array}{l}\text { PENDIDIK DAN } \\
\text { TENAGA } \\
\text { KEPENDIDIKAN }\end{array}$} & Kolaborasi & 15 & \multirow{3}{*}{11} \\
\hline & Interaksi & 14 & \\
\hline & Kinerja & 14 & \\
\hline \multirow{3}{*}{$\begin{array}{l}\text { SARANA } \\
\text { dan } \\
\text { PRASARANA }\end{array}$} & Perencanaan & 14 & \multirow{3}{*}{13,3} \\
\hline & Pengadaan & 13 & \\
\hline & Perawatan dan Perbaikan & 13 & \\
\hline \multirow{3}{*}{ PEMBIAYAAN } & Sumber Dana & 13 & \multirow{3}{*}{13,6} \\
\hline & Alokasi Pembiayaan & 14 & \\
\hline & Mekanisme Pertanggungjawaban & 14 & \\
\hline \multirow{4}{*}{ AKADEMIK } & Isi & 13 & \multirow{4}{*}{14,5} \\
\hline & Proses & 15 & \\
\hline & Penilaian & 15 & \\
\hline & Kelulusan & 15 & \\
\hline \multirow[t]{3}{*}{ LINGKUNGAN } & Perencanaan & 14 & \multirow{3}{*}{13,3} \\
\hline & Pengembangan & 12 & \\
\hline & Evaluasi & 14 & \\
\hline \multicolumn{2}{|c|}{ Total Komulatif } & 252 & 13,2 \\
\hline \multicolumn{2}{|c|}{ Percentase dan Kategori $13,2 / 15 \times 100 \%=0,88 \%$} & \multicolumn{2}{|c|}{ B ( Baik) } \\
\hline
\end{tabular}


Masyhudi

\section{Pembahasan}

Berdasarkan paparan hasil tindakan penelitian diatas yang dilihat dari kondisi awal kinerja warga sekolah, peneliti menyusun berbagai rencana, tindakan, kegiatan observasi keterlaksanaan program pada tahap (siklus I) yang di mulai 17 Juli 2017 sampai dengan 29 September 2017. Hasil analisis angket refleksi penerapan budaya positif menunjukkan adanya peningkatan dari keadaan awal dengan pesentase $\mathbf{0}, \mathbf{4 5} \%$ menjadi 0, $61 \%$ ( kategori Cukup ) pada siklus I dengan peningkatan dengan peningkatan sebesar $16 \%$ dan setelah pelaksanan tindakan siklus II didapatkan persentases rekapitulasi angket refleksi budaya kerja positif sebesar $\mathbf{0 , 8 8} \%$ ( kategori Baik), dan peningkatan dari percentase siklus I ke siklus II sebesar $27 \%$.

\section{Simpulan}

Berdasarkan hasil dan pembahasan penelitian penerapan budaya kerja positif untuk meningkatkan mutu pendidikan pada SMP negeri 1 Sakra Barat dapat disimpilkan sebagai berikut: (1 ) Langkah-langkah penerapan budaya kerja positif di satuan pendidikan SMP Negeri 1 Sakra Barat dapat dilakukan melalui : a) perumusan visi, misi, dan tujuan sekolah baik tujuan jangka pendek, menengah, dan jangka panjang, dan perumusannya diputuskan melalui kegiatan rapat kepala sekolah, dewan pendidik dan tenaga kepndidikan, serta mengundang komite sekolah, b) memaksimalkan partisipasi semua warga sekolah dalam perencanaan dan pengembangan 6 (enam ) bidang pokok Perencanaan dan Pengembangan Sekolah (PPS), c) mengembangkan hubungan kemitraan dengan unsur eksternal lembaga khususnnya dengan komite dan wali murud (2) Respon personil sekolah terhadap penerapan budaya kerja positif dalam kategori baik, hal ini terlihat hasil analisa angket refleksi budaya kerja yang menunjukkan peningkatan persentase dari kondisi awal ke siklus I sebesar $16 \%$ dan peningkatan dari siklus I ke siklus II sebesar $27 \%$. Respon personil sekolah juga secara nyata terlihat dari hasil proses pembelajaran dan pembimbingan terhadap siswa baik program kokurikuler maupun ekstrakurikuler sehingga SMP negeri 1 Sakra Barat secara akademik masuk peringkat 10 (sepuluh 
besar) dalam hasil penilaian akhir semester ganjil 2017/2018, dan prestasi lomba yang diraih siswa dibidang olah raga mampu menembus tingkat Kabupaten dan provinsi.

\section{Daftar Pustaka}

Hidayat syamsul. 2017. Membangun Budaya Kerja Organisasi, makalah, BKD Provinsi NTB.

2017. Budaya Organisasi Sekolah dan Kiberja Guru, www, mediashare.com. diakses tanggal 24 Agustus 2017, Pukul 16:00 Wita.

Hamidi. 2017. Terbentuknya Perilaku dan Sikap Budaya Kerja Positif, artikel, 123.dok.com, diakses 03 september 2017 Pukul 14.25 Wita.

Imron Ali, Dkk. 2003. Manajemen Penddikan Analisa Substantif dan Aplikasinya dalam Institusi Pendidikan. UN Malang.

Iskandar Uray. 2016. Budaya Kerja Guru, artikel, https://urayiskandar.com diakses 03 Juli 2017 Pukul 13.30 Wita.

Mulyasa. 2004. Menjadi Kepala sekolah Profesional, dalam konteks Menyukseskan MBS, dan KBK. Rosda Karya

Mulyasa. 2002. Manajemen Berbasis sekolah, konsep, strategy, dan implementasi. Rosda karya.

P2TK BPSDM. 2014. Manajemen dan Kepemimpinan Sekolah, Bahan Ajar Impelementasi Kurikulum 2013 untuk Kepala Sekolah, September Jakarta.

P4TK, Kementerian Pendidikan Nasioanal 2010, panduan Penulisan Proposal dan laporan PTK dan PTS, Maret Jakarta.

80 Fondatia: Jurnal Pendidikan Dasar 
Rohiat. 2008. Manajemen sekolah, Teori dasar dan praktik. Reflika Aditama.

Syahodih nana, dkk. 2006. Pengendalian Mutu pendidikan Sekolah Menengah, Konsep, prinsip, dan Instrumen. Reflika Aditama.

Syaefudin udin, Dkk. 2005. Perencanaan pendidikan suatu Pendektan konfrehensif. Rosda karya.

Seravine. 2016. Budaya Organisasi dan Budaya Kerja, artikel, http://tugaskuliahanakmenej.blogspot.co.id diakses tanggal 03 Juli 2017 Pukul 14. 40 Wita. 